\title{
611 温熱画像を用いた生活空間の温熱快適性評価法
}

Evaluation Method of Thermal Amenity in Living Environment Using Thermal Images

学 小笠原英子（筑 波 大） O学 蓸田 豊（筑 波 大）
正 水谷 孝一（筑 波 大）
Hanako OGASAWARA', Yutaka SONODA', Koichi MIZUTANI' and Yukio ISHIKAWA ${ }^{2}$
'University of Tsukuba, Tsukuba 305-8573, Japan, ${ }^{2}$ Takenaka R\&D Institute. Inzai 270-1395, Japan

1. はじめに

人間が快適だと思える室内環境は、その時の天候や室内の 温度、湿度、風速、服装、活動量等によって異なる ${ }^{[1,2]}$ 。そ こで、それらの要素を考慮し、人間の温冷感と関連付けた指 標として 1994 年に予想平均温冷感申告指標(Predicted Mean Vote: PMV)が ISO7730 で標準化された。PMV は温熱環境の 良否を判断する基準として世界中で使用されている ${ }^{[3,4]}$ 。しか し、ISO7730 では PMV 值を求める計算において重要な人体 の着衣表面温度を式(1)-(4)で示寸ような複雑な繰り返し計算 による推測値より得ている。そのため繰り返し計算を近似式 によって代用する手法 ${ }^{[5]}$ が用いられているが、その多くが計 算結果に誤差を生じてしまうことが指摘されていた ${ }^{[6,7] 。}$

本研究では、生活空間内にサーモカメラ、 $\operatorname{Tr}$ 式微風速計を 設置し、室内をモニタリングし、そこから得られた熱画像か ら人体部分を抽出し着衣表面温度とし、それ以外の部分を平 均輻射温度とし、PMV 值を算出し、その結果と既存の PMV 值計算法による計算結果との比較を行った。

\section{2. 原 理}

PMV 指標は、0 を含む 03 の 7 段階で、「暑い」、「寒い」を 表現しており、土1に入れば、快適な状態とされている。この PMV 值は、Table I に示すパラメータを用いて計算される。 本研究での特徴は、Table I の上二つのパラメータを Fig.1 に 示すような熱画像から直接計測するところにある。

Table I Parameters for PMV calculation

$\begin{array}{lll}\text { 着衣表面温度（熱画像における人体部分） } & t_{c l} & { }^{\circ} \mathrm{C} \\ \text { 平均輻射温度 (人体以外の部分) } & \bar{t}_{r} & { }^{\circ} \mathrm{C} \\ \text { 人体の表面積における代謝率 } & M & \mathrm{~W} / \mathrm{m}^{2} \\ \text { 単位面積当たりの外部からの仕事量 } & W & \mathrm{~W} / \mathrm{m}^{2} \\ \text { 着衣による熱抵抗 } & I_{c l} & \mathrm{~W} / \mathrm{m}^{2} \\ \text { 室内温度 } & t_{a} & { }^{\circ} \mathrm{C} \\ \text { 人体に対する相対風速 } & v_{u r} & \mathrm{~m} / \mathrm{s} \\ \text { 水蒸気分压 } & p_{a} & \mathrm{~Pa} \\ \text { 皮唐表面積に対する着衣時の表面積比 } & f_{c l} & \\ \text { 対流熱伝達係数 } & h_{c} & \mathrm{~W} / \mathrm{m}^{2}\end{array}$

$$
\begin{aligned}
& \mathrm{PMV}=\left(0.303 e^{-0.036 M}+0.028\right)\{(M-W) \\
& -3.05 \times 10^{-3} \times[5733-6.99(M-W) \\
& \left.-p_{a}\right]-0.42 \times[(M-W)-58.15]-1.7 \\
& \times 10^{-5} M\left(5867-p_{a}\right)-1.4 \times 10^{-3} M \\
& \times\left(34-t_{a}\right)-3.96 \times 10^{-8} f_{c l} \times\left[\left(t_{c l}+273\right)^{4}\right. \\
& \left.\left.-\left(\overline{t_{r}}+273\right)^{4}\right]-f_{c l} h_{c}\left(t_{c l}-t_{a}\right)\right\} \text {. } \\
& t_{c l}=35.7-0.028(M-W)-I_{c l}\{3.96 \\
& \times 10^{-8} f_{c l} \times\left[\left(t_{c l}+273\right)^{4}-\left(\overline{t_{r}}+273\right)^{4}\right] \\
& \left.+f_{c l} h_{c}\left(t_{c l}-t_{a}\right)\right\} \text {. } \\
& h_{c}=\left\{\begin{array}{rr}
2.38\left(t_{c l}-t_{a}\right)^{0.25}>12.1 \sqrt{v_{a}} \text { のとき } \\
2.38\left(t_{c l}-t_{a}\right)^{0.25} \\
2.38\left(t_{c l}-t_{a}\right)^{0.25}<12.1 \sqrt{v_{a}} \text { のとき } \\
12.1 \sqrt{v_{a}}
\end{array}\right. \\
& f_{c l}= \begin{cases}I_{c l} \leq 0.0780 \text { とき } & 1.00+1.290 I_{c l} \\
I_{c l}>0.0780 \text { とき } & 1.05+0.645 I_{c l}\end{cases}
\end{aligned}
$$

Fig.1 に原熱画像 $\mathrm{P}_{n}$ から着衣表面温度 $\left(t_{c l}\right)$ と平均輻射温度 $\left(\bar{t}_{r}\right)$ を算出する手順を示す。人体部分を抽出するために $\mathrm{P}_{n}$ を闘値 処理[8]を行い高温領域画像 $\mathrm{P}_{\mathrm{b} 1 n}$ を抽出する。それに 4 方向 Laplacian filter 処理 ${ }^{[8,9]}$ を施し 2 值化像輪郭像を得る。

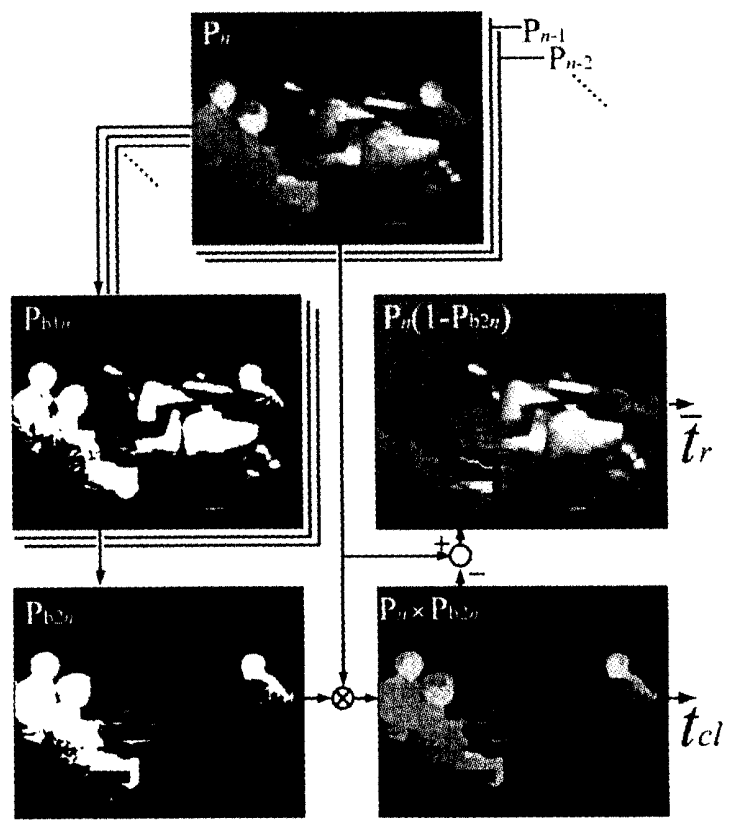

Fig. 1 Procedure of an extraction for surface temperature of clothing and mean radiant temperature from thermal images. 
5 分間分の複数枚の 2 值化輪郭画像を加算寸ることで人体以 外の静止高輻射物の輪郭が強調される。その画像に閾値処理 を行つた後、塗りつぶし処理を行うことで 2 值化高輻射物画 像が得られる。更に、2 值化高温領域画像と 2 値化高輻射物 領域画像との差をとることで、Fig.1 に示す 2 値化人体領域画 像 $\mathrm{P}_{\mathrm{b} 2 n}$ を得る。原画像と 2 值化人体領域画像の要素同士の積 をとることで原画像の人体領域画像 $\mathrm{P}_{n} \times \mathrm{P}_{\mathrm{b} 2 n}$ を得る。一方、 背景領域画像 $\mathrm{P}_{n}\left(1-\mathrm{P}_{\mathrm{b} 2 n}\right)$ は原画像と人体領域画像 $\mathrm{P}_{n} \times \mathrm{P}_{\mathrm{b} 2 n}$ との 差から抽出できる。最終的に、それぞれの画像の値を持つ要 素の平均をとることで人体の着衣表面温度 $t_{c l}$ と平均輻射温 度 $\bar{t}_{r}$ を算出し、PMV 值を導く。

\section{3. 実}

実験機材にはサーモカメラ(TH5100/NEC)、Tr 式微風速計 (AM-09T / RION)、Pentium III 750 MHz (PCV-72 / SONY)を使 用した。実験時にはサーモカメラを実験室の隅に、微風速計 を部屋の中央に設置して 30 秒間隔で熱画像を取得した。被 験者はには撮影範冊内での活動以外は制限しなかった。

計測時、室内では終始暖房設備は稼動しており平均風速 $0.10 \mathrm{~m} / \mathrm{s}$ 、平均水蒸気分压 $1.00 \times 10^{3} \mathrm{~Pa}$ 、活動量 $70 \mathrm{~W} / \mathrm{m}^{2}$ 、平 均着衣量 $0.157 \mathrm{~m}^{2} \cdot \mathrm{K} / \mathrm{W}$ であった。計測後、得られたデー夕 を用いてシミュレーションを行い本方式による実験結果と ISO による手法とを比較した。実験で得られた原画像と処理 した画像の一例は既に Fig. 1 に示している。この環境におけ る 25 分間の着衣表面温度と PMV 值の時間推移を、それぞれ Fig. 2 と Fig. 3 に示す。二つの図ともにISOによる值と本方 式による值を併記しているが、両者ともに概极一致した值で あり、繰り返し計算によらない熱画像から直接計測した着农 表面温度と平均輻射温度を用いても、被験者の「少し暑い という PMV 值が得られた。

\section{4. むすび}

本研究は、ISO7730(1994)で標準化されている予想平均温冷 感申告指標(Predicted Mean Vote: PMV)における新しい測定法 を提案した。本研究で提案する熱画像を用いる方法では、サ 一モカメラを用いて室内をモニタリングし、取得した熱画像 から人体領域を抽出し、そこから着衣表面温度を得ているた め、実際の状況を反映した信頼性の高い着衣表面温度が得る ことができた。それにより、一定の精度を持った PMV 值を 計算出来ること、それらが室内環境や人体に何ら影響を与え

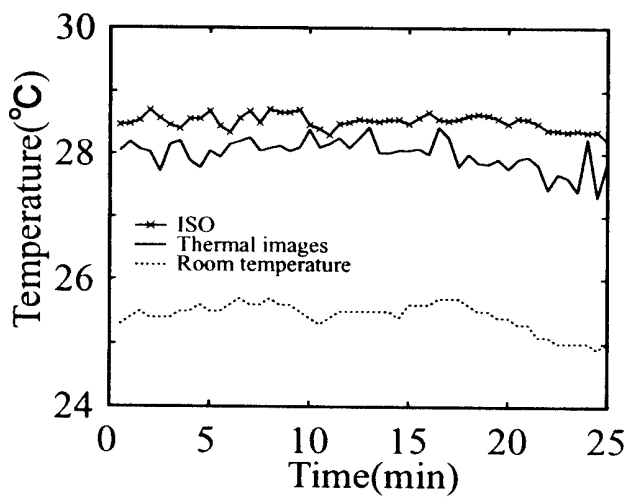

Fig. 2 Time course for 25 minutes of the room temperature and surface temperatures of clothing calculated by ISO and our method.

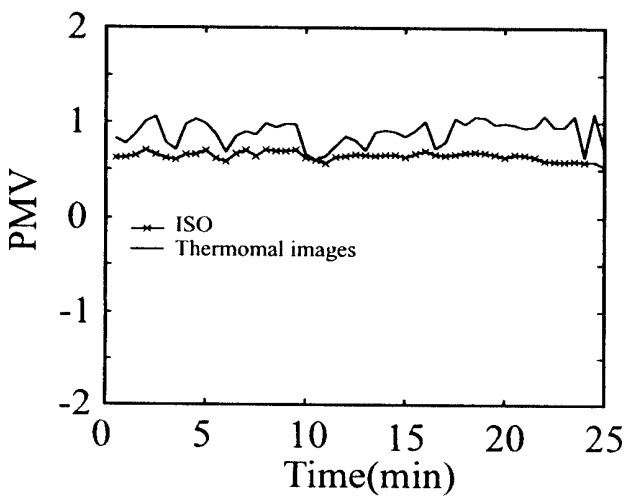

Fig. 3 Time course for 25 minutes of the PMVs detected by ISO and our method.

ることなく計測・評価できることが分かった。今後は、画像 の人体部分抽出処理の改善などを図る予定である。

\section{参考文献}

|11 尾関義一, 小西正哲, 成田千恵, 田辺新一: “日射が 温熱感に 与える 影響に関寸る 研究 (その 4) - 人体と矩 形面との 距 離が $2 \mathrm{~m}$ 以下の 場合の 数值計算による 全身と 矩形面との 形態係数一,”日本建築学会学術講演梗概集, pp.375-376 (1999)

[2] P. Tibaut and B. Weisler: "Thermal comfort assessments of indoor environments by means of CFD," 8th International Conference on Air Distribution in Rooms, Denmark,(2002).

[3] ISO 7730: Moderate thermal environments Determination of the PMV and PPD indices and specification of the conditions for thermal comfort, ISO., Geneva (1994).

[4] S. Atthajariyakul and T. Leephakpreeda: "Real-time determination of optimal indoor-air condtion for thermal comfort, air quality and efficient energy usage," 8th International Conference on Air Distribution in Rooms, Denmark, pp.425-428 (2002).

[5] Guodong Ye, Changzhi Yang, Youming Chen, and Yuguo Li: "A new approach for measuring predicted mean vote (PMV) and standard effecttive temperature(SET")," Building and environment,38, pp.33-44(2003).

[6] A. Michael Humphreys and J. Fergus Nicol: "The validity of ISO-PMV for predicting comfort votes in every-day thermal environments," Energy and Buildings, 34, pp.667-684 (2002)

[7] Maher Hamdi, Gérard Lachiver, and François Michaud: "A new predictive thermal sensation index of human response," Energy and Buildings, 29, pp. 167-178(1999)

[8] Gragory A. Baxes 著, 田中 總太郎, 大宅伊久雄、杉村 俊郎, 吉田 隆義, 和宇慶 康:"ディジタル画像処理入阴,”啓学出版株 式会社，東京,(1988)

|9| 高井信勝,”「信号処理」画像処理」のための MATLAB 入阳「增補 版，”工学社,東京, (2002) 